\title{
メシル酸イマチニブの膠原病治療薬としての可能性
}

\author{
亀田秀人
}

\section{Imatinib mesylate as a novel therapeutic drug for systemic rheumatic diseases}

\author{
Hideto KAMEDA, MD, PhD \\ Division of Rheumatology/Clinical Immunology, Department of Internal Medicine, Saitama Medical Center, \\ Saitama Medical University
}

(Received March 31, 2007)

summary

Platelet-derived growth factor (PDGF) is a topic in the pathophysiology of various systemic rheumatic diseases. For example, autoantibody against PDGF receptor was identified in patients with systemic sclerosis. Imatinib mesylate has been well tolerable and widely used for chronic myeloid leukemia and gastrointestinal stromal tomor. Imatinib also inhibits the activation of $\mathrm{c}-\mathrm{Abl}$, which is a key downstream molecule of transforming growth factor-beta signaling, and PDGF receptors. Thus, imatinib effectively suppresses the activation and proliferation of fibroblasts, mesangial cells and smooth muscle cells. Therefore, imatinib may overcome the limitation of current therapeutic strategy with corticosteroids and immunosuppressive agents for refractory diseases.

Key words platelet-derived growth factor; rheumatoid arthritis; fibroblast; systemic sclerosis; interstitial lung disease

\section{抄 録}

強皮症における血小板由来増殖因子（PDGF）受容体刺激抗体の発見をはじめとして，膠原病の様々な病態にお いてPDGF の関与が注目されている。メシル酸イマチニブは慢性骨髄性白血病や消化管間葉腫瘍（gastrointestinal stromal tomor：GIST）に対する耐用性の高い治療薬として広く用いられているが， transforming growth factor- $\beta$ の作用に重要な c-Abl や PDGF 受容体の活性も阻害する.イマチニブは線維芽細胞やメサンギウム細胞, 平滑筋 細胞の活性化や増殖に対して強力な抑制作用を示す．副腎皮質ステロイドや免疫抑制薬を中心とした治療に抵抗性 であった様々な病態を，イマチニブなどによる間葉系細胞を標的とした新規治療ストラテジーにより克服しうる可 能性が開けてきた.

\section{はじめに}

膠原病は自己免疫という免疫系の異常におそらく 起因すると考えられる全身性の慢性炎症性疾患であ る. 自己反応性リンパ球の存在や自己抗体は同定さ れていても, 膠原病における免疫偏向の実態はどの 疾患でも不明である. そのため免疫偏向を矯正する 原因療法がなく，予防や根本的治療にはほど遠い免 疫抑制あるいは炎症制御が今日の治療の現実であ る。そのため多くの疾患に拈いて，治療介入による 予後の向上は副腎皮質ステロイド（以下，ステロイ ド）に寄与するところが大きく，ステロイドの有効

埼玉医科大学総合医療センター リウマチ・膠原病内 科 性が比較的低い強皮症（systemic sclerosis; SSc）の 場合は，専門医による診療が患者の自然経過を大き く変えているとは言いがたい，これはステロイド以 降の治療薬の進歩も，例えば関節リウマチ（RA） に打けるメトトレキサートや抗腫瘍壊死因子 $\alpha$ $(\mathrm{TNF} \alpha)$ モノクローナル抗体のごとく, 白血球, 特に $\mathrm{T}$ 細胞や $\mathrm{B}$ 細胞などのリンパ球や単球/マクロ ファージを標的とした治療が中心であることによる (図 1).

従って, 現在のいわゆる難治性病態あるいは難治 症例はこれらの治療に不応であることを意味し，す なわち線維芽細胞や血管内皮細胞など他の細胞を標 的とした治療の必要性を示唆する. 実際, 膠原病の さまざまな疾患・病態において血小板由来増殖因子 (platelet-derived growth factor ; PDGF) による線維 


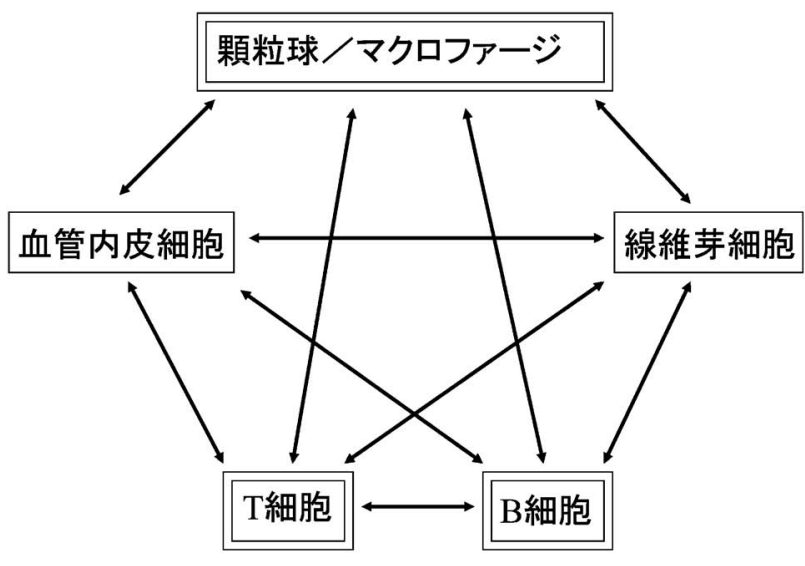

図 1 膠原病の炎症性病態に抢ける主な治療標的細胞 膠原病に打いては組織を問わず炎症の局所で様々な細胞が 複雑なコミュニケーションを行い，炎症の持続や増幅を惹起 している．従来の治療の主な標的細胞を二重囲いで示した.

芽細胞の活性化が重要な役割を果たしていること や，メシル酸イマチニブ（以下，イマチニブ）など による PDGF 受容体（PDGF-R）の活性化阻害が 膠原病治療に有望であることを示唆する報告が近年 相次いでいる，そこで，本稿では RAの破壊性関節 炎や多発性筋炎/皮膚筋炎（polymyositis/dermatomyositis；PM/DM）などの膠原病に伴う間質性肺 炎, ループス腎炎, 肺高血圧症などの膠原病の様々 な難治性病態におけるPDGF の関与やイマチニブ を用いた基礎研究に関するこれまでの文献報告を総 括し，難治性病態打開へ向けた膠原病治療の新たな 方向性を探ってみたい。

\section{PDGF-R のシグナル伝達とイマチニブの作用機序}

PDGF は線維芽細胞，マクロファージ，血管平 滑筇細胞, 血小板など様々な細胞から産生される.

PDGF にはジスルフィド結合による 2 量体 $\mathrm{AA}$, $\mathrm{AB}, \mathrm{BB}$ ，さらに新たに同定された $\mathrm{CC}, \mathrm{DD}$ がこれ までに知られており，一方 PDGF-R は $\alpha$ と $\beta$ の小 モあるいはへテロ 2 量体として結合，活性化され る1〜3). PDGF-AA は PDGF-R $\alpha \alpha, \mathrm{AB}$ と $\mathrm{CC}$ は $\alpha \alpha$ と $\alpha \beta, \mathrm{BB}$ は全て，DD は $\alpha \beta ， \beta \beta$ とそれぞれ結 合する。リガンドが結合し 2 量体となった PDGF$\mathrm{R}$ は細胞質内領域のチロシンリン酸化を通じて多く のアダプター蛋白やリン酸化・脱リン酸化酵素を活 性化させる（図 2)。その結果，線維芽細胞や平滑 筋細胞などの増殖を促進し， transformation にも関 与するとされる。また PDGF 刺激により RA 滑膜 線維芽細胞における $\mathrm{NF}-\kappa \mathrm{B}$ 活性化を介した $\mathrm{IL}-1 \beta$ や IL-8 産生が方進し, $\mathrm{TNF} \alpha$ との相乗効果が見ら

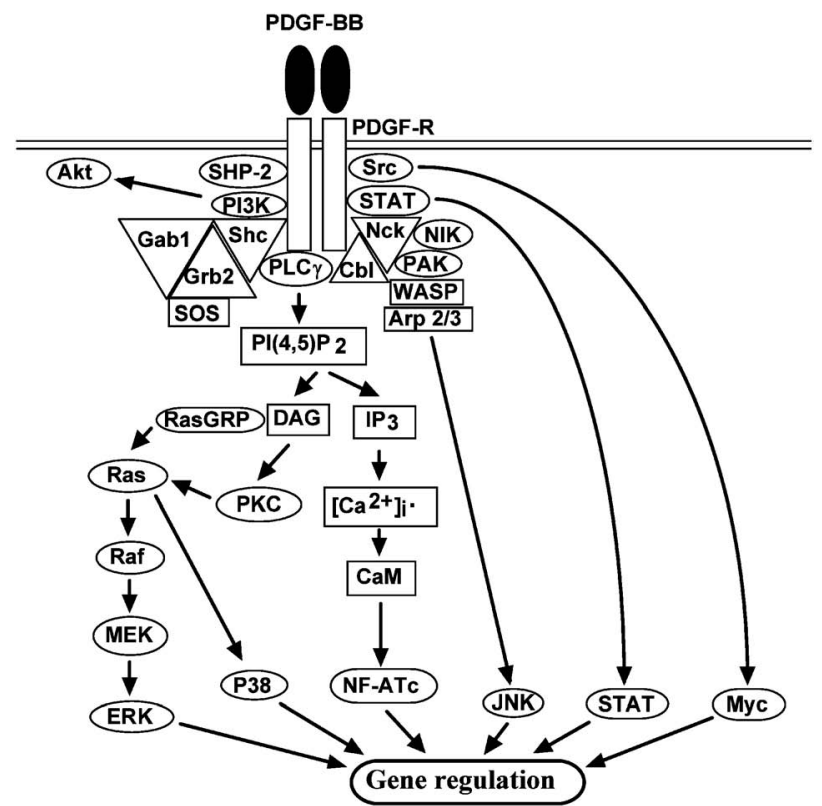

図 2 PDGF-R の刺激伝達経路

PDGF の 2 量体が受容体に結合すると，様々なアダプ ター蛋白やリン酸化酵素の活性化を介して, 細胞の機能変化 が生じる.

れることが報告されて抢り4)，炎症の増幅や持続に も関与すると考えられる。

イマチニブは Abl， Bcr-Abl， PDGF-R， c-Kit (stem cell factor 受容体) に対して，それぞれ 0.1$0.3 \mu \mathrm{M}, 0.25 \mu \mathrm{M}, 0.12-0.15 \mu \mathrm{M},<1 \mu \mathrm{M}$ の $\mathrm{IC}_{50}$ で チロシンリン酸化活性の抑制効果を示す5,6)。やや 高用量（ $\mathrm{IC}_{50}=1.42 \mu \mathrm{M} ）$ ではマクロファージコロ ニ一刺激因子 $(\mathrm{M}-\mathrm{CSF})$ 受容体である $\mathrm{c}-\mathrm{fms}$ の活 性化も阻害するようである7)．Bcr-Abl に対する優 れた抑制効果から慢性骨髄性白血病の治療薬として 画期的な成功を収めたのは周知の通りである その後, c-Kit の活性阻害により消化管間葉腫瘍 （gastrointestinal stromal tumor：GIST）の治療薬と しても優れた効果を示し10), 米国 FDA で承認され た.さらにイマチニブの PDGF-R 活性抑制効果も 注目され, 骨髄増殖性疾患の一部に対する有効性が 報告された11)。そして前立腺癌をはじめとしたいく つかの腫瘍に対しても臨床試験が行われている12)。

\section{RA の破壊性関節炎}

RA 患者滑膜は滑膜細胞の異常増殖, 血管新生, $\mathrm{CD} 4$ 陽性 $\mathrm{T}$ 細胞を含めた炎症細胞浸潤に特徵づけ られる13). RA の発症や病態に $\mathrm{T}$ 細胞の関与がある ことは疑いないが， $\mathrm{T}$ 細胞非依存性の経路の存在も ほぼ確立されつつある ${ }^{14)}$. 実際，RA の滑膜細胞は 活性化され，transformationを生じていると考えら 
れている15,16).すなわち, 細胞形態学的変化, 特に PDGF の存在下での anchorage 非依存性の増殖や 接触阻止 (contact inhibition) 喪失 ${ }^{17)}$, oncogene の活性化 ${ }^{18)}$, monoclonal あるいは oligoclonal な増 殖19), さらに SCID (severe combined immunodeficient）マウスにおける移植滑膜組織の軟骨への浸 潤20)などが次々と報告されている。こうした変化は 変形性関節症（OA）患者滑膜ではあまり見られな ( $15 \sim 20)$.

筆者らは以前に Syrian hamster embryo fibroblast の in vitro transformationの系を用いて, preneoplastic な段階にある細胞が増殖因子の存在下で anchorage 非依存性に増殖するという RA 滑膜細胞類 似の性質を示すことを報告した ${ }^{21)}$ 。この細胞ではア ダプター蛋白 Gab1 の pleckstrin-homology $(\mathrm{PH})$ ドメインがほとんど欠失しており，これが増殖因子 のシグナル伝達異常, ひいては transformation を 生じていると考えられた.

PDGF-R が RA 患者滑膜細胞表面に発現増強し て抢り, PDGF 刺激による増殖促進が報告されて いることから ${ }^{17,22 ~ 25)}$, 次に RA 滑膜細胞の PDGF 刺激による活性化をイマチニブ（STI571）が抑制 するかどうかを検討した．RA 滑膜細胞を $10 \mathrm{ng} / \mathrm{ml}$ の PDGF で 1 分間刺激すると, PDGF-R およびそ の下流に位置するアダプター蛋白 Gab1，Gab2 の チロシンリン酸化を生じる26)。このチロシンリン酸 化は RA 滑膜細胞をPDGF 刺激前にイマチニブ 1 $\mu \mathrm{M}$ で 1 時間前処理するとほぼ完全に抑制された. そこで次に，イマチニブの RA 滑膜細胞増殖抑制効 果を anchorage 依存性増殖（図 3A）と anchorage 非依存性増殖（図 3B）の双方において検討した。 5 $\%$ fetal bovine serum（FBS）をコントロールとする と, FBS 濃度を 20\%に増加させると RA 滑膜細胞 の anchorage 依存性および非依存性増殖のいずれも 促進された. PDGF $(10 \mathrm{ng} / \mathrm{ml})$ 刺激による促進効 果も双方で認められたが，特に anchorage 非依存性 増殖では 20\% FBS に匹敵した．イマチニブを同時 に投与して培養すると，1 $1 \mu \mathrm{M}$ で PDGF 刺激による anchorage 依存性および非依存性増殖をほぼ完全に 抑制した.

かかる知見はまもなくフィンランドのグループに より再現された ${ }^{27)}$.ラットのコラーゲン誘発関節炎 モデルでイマチニブが関節破壊を遅延させたが，破 骨細胞の形成を阻害するも活性は低下させず，関節 腫脹の改善も認めなかった ${ }^{28)}$. しかし DBA/1 マウ (a)

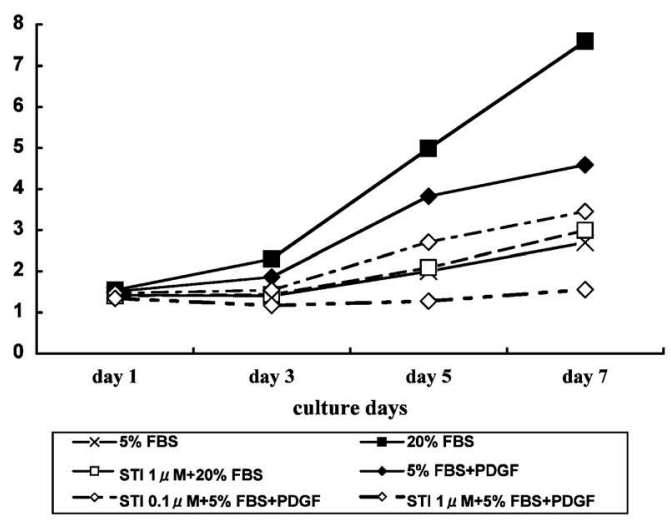

(b)

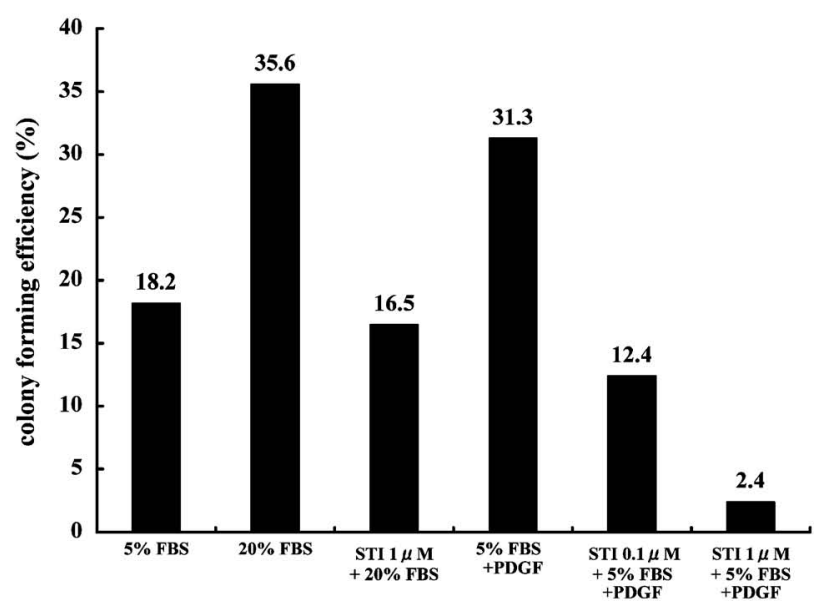

図 3 STI571 による RA 滑膜細胞の増殖抑制25)

（A） RA 滑膜細胞を 96 穴プレートで 7 日間培養した． $5 \%$ FBS（×）をコントロール，20\% FBS（吕）を陽性コ ントロールとし, $10 \mathrm{ng} / \mathrm{ml}$ の PDGF-BB 刺激（・）に よる増殖促進効果, 抢よび STI571 による $20 \%$ FBS 刺

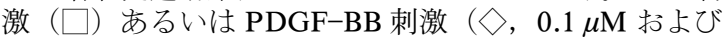
$1 \mu \mathrm{M}$ は各々細いまたは太い破線で示す）に対する抑制 効果を検討した。

（B） RA 滑膜細胞を 6 穴プレートを用いた $0.3 \%$ 軟寒天培 地で 21 日間培養し, $60 \mu \mathrm{m}$ 以上のコロニー形成率を調 べた.

スを用いたコラーゲン誘発関節炎モデルではイマチ ニブにより滑膜炎，パンスス形成，骨びらんのいず れも治療域の投与量で抑制され, in vitroでは肥満 細胞の c-Kit 活性化は滑膜線維芽細胞の PDGF-R 活性化と同様に $1 \mu \mathrm{M}$ で十分抑制され, $\mathrm{B}$ 細胞や $\mathrm{T}$ 細胞の活性化抑制には約 10 倍の高用量を要し た29). 今後さらに多くのモデル動物での詳細な検討 が必要である。しかしまだ少数例ではあるが，実際 の臨床でイマチニブが RA 患者に投与され有効であ ったことが報告されている30,31)．従って血球減少な ぞへの留意が必要ながら, 感染症リスクなどから治 療選択肢がほとんどない RA 患者や, 従来の治療で 寛解導入困難な患者への治療薬として有望である. 


\section{膠原病に伴う間質性肺炎}

膠原病は “collagen-vascular diseases” とも称さ れ，血管病変に伴い多臓器の炎症を生じるが，なか でも肺は豊富な血流を受け，腎蔵を凌いで膠原病に おいて最も障害されやすい臓器となっている，膠原 病に見られる肺病变は間質性肺炎が主体であり， その頻度は用いる検査の精度により異なるが，本邦 では RA, PM/DM, SSc, 顕微鏡的多発血管炎 (microscopic polyangiitis ; MPA) で 30-50\% と高頻 度に認められる。膠原病に伴う間質性肺炎の経過か ら久た病型は，1）発症から 1 ヶ月以内（急性）， あ るいは 2-3 ヶ月以内（亜急性）に進行・増悪する （亜）急性型，2）呼吸不全となるまでには 6 ヶ月以 上を要し, 徐々に線維化が進行する慢性型，3）慢 性型の（亜）急性増悪，4）胸部 CT p呼吸機能検 査のガス拡散能などで軽度の異常を認めるも無症状 で経過する無症候性型，の4つに大別される ${ }^{32}$. 間 質性肺炎は他の臨床症状にしばしば先行して発症 し，膠原病の早期診断が困難となる。膠原病患者の 中には重複症候群と診断されなくても，他の膠原病 の要素を兼ね備えている場合が少なくないが，疾患 固有の肺病変としては, SLE では急性型が原則で, SSc では逆に急性型や急性増悪はまず無いとされ，

一方 RA，PM/DM，MPA では上記 4 つの経過病型
のいずれもが経験される.

特発性間質性肺炎 (idiopathic interstitial pneumonia；IIP）に打いては, 臨床診断, 画像診断, 病理組織学的診断の三者を関連づけた国際的共同 声明が American Thoracic Society と European Respiratory Society から提唱され ${ }^{33)}$ ，本邦でも日本 呼吸器病学会と厚労省研究班により診断 · 治療の手 引きが作成された。膠原病では必ずしも IIP に対応 する訳ではなく, 例えば画像や病理組織学的に usual interstitial pneumonia (UIP) と考えられる膠 原病症例の予後は総じて特発性肺線維症より良好で ある.とはいえ, 長期的には 5-10 年の経過で在宅 酸素療法や死亡にまで至ることもしばしばである. （亜）急性型の中にはステロイド反応性の良好な, 組織学的には organizing pneumonia (OP) ある いは cellular non-specific interstitial pneumonia (NSIP) とされるものもある一方で, 特に筋炎所見 の軽微 (clinically amyopathic) な DM (C-ADM) では，(亜）急性型でありながら初期からの大量久 テロイドや作用機序の異なる複数の免疫抑制薬併用 にも全く反応せず，診断から数ヶ月以内に死亡する 極めて予後不良な例が目立つ ${ }^{34)}$. かかる症例に対し ては免疫抑制をさらに強化すべきなのかもしれない が, 感染リスクからも可能なら別の標的細胞に対す る治療の併用を試みたいところである（図 4)。予

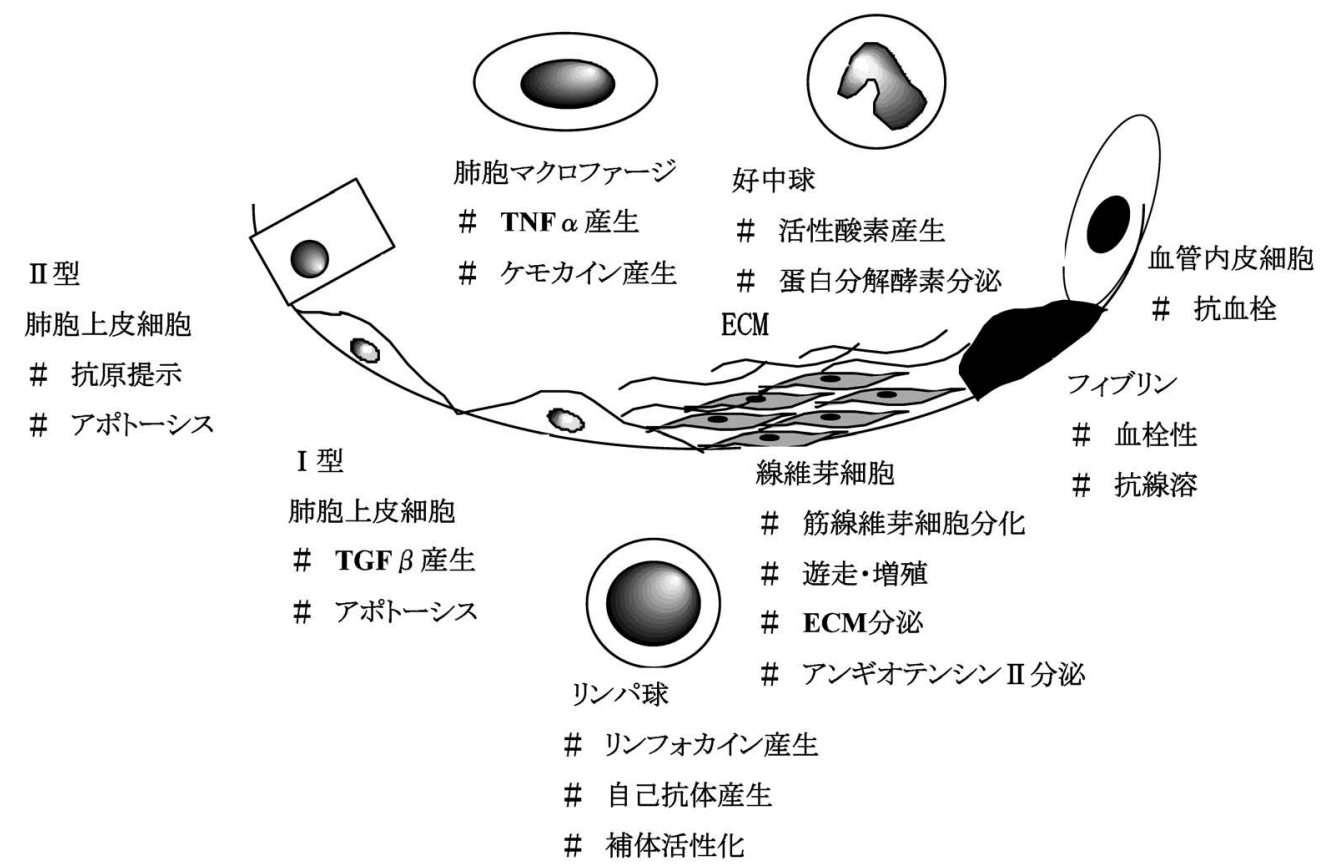

図 4 間質性肺炎の病態と治療標的

自己に対する免疫応答に関連して CD8 陽性細胞主体のリンパ球浸潤が生じる. 肺胞上皮細胞のアポトーシスに対して十分な再 上皮化が行われないと血栓形成や ECM の過剩産生により線維芽細胞の増殖が生じる. 図 1 との対比で従来の治療戦略に欠如し ていたものが分かる。 
後不良な急速進行型間質性肺炎を生じる C-ADM 症例は日本からの報告が圧倒的に多く35)，ゲフィチ ニブ，レフルノミドなどの薬剤性間質性肺炎を見て も日本人は欧米人に比べて間質性肺炎を生じやすい 個体側の感受性（あるいは環境要因）があるのかも しれない。

こうした免疫抑制療法不応性の間質性肺炎に対し てもイマチニブが有効かもしれない. Daniels らは TGF- $\beta$ の下流に位置するシグナル分子として $\mathrm{c}-$ Abl に着目した。c-Abl は培養下で上皮細胞には発 現せず線維芽細胞に発現しており，TGF- $\beta$ 刺激に よる myofibroblastへの変化, 増殖, そしてフィブ ロネクチンやコラーゲンなどの細胞外基質（extracellular matrix ; ECM）産生にも関与しており， これらはすべてイマチニブにより抑制された ${ }^{36)}$.さ らにブレオマイシ誘発肺障害もイマチニブで阻止さ れた。放射線肺障害モデルに扔いても，イマチニブ は他の PDGF-R などのチロシンキナーゼ阻害薬 （SU9518，SU11657）々同様に 20 Gy という比較的 低線量暴露による肺障害を抑制することが高分解能 CT 画像, 組織の両面から確認され, 生存を延長さ せた ${ }^{37)}$. 興味深いことに放射線被爆前に投与開始す るよりも，被爆後に投与開始した方がやや高い有効 性を認めたことである.ブレオマイシ誘発肺障害の マウスモデルではイマチニブは早期投与のみ有効で あったが38)，ラットモデルではステロイドが早期投 与のみ有効であったのに対して，イマチニブは早期 投与でも後期の炎症が収束し線維化主体となった時 期でも同様の有効性が示された ${ }^{39)}$. 免疫抑制療法の 場合は動物モデルでも早期投与開始がより有効であ ることが常識であり，予防には有効でも治療効果は ないと考えさせるデータは枚挙に暇が無い。従っ て，イマチニブはステロイドパルス療法や免疫抑制 薬に不応であった場合に投与してみる価值があるこ とが示唆される.

培養組織学的にUIP が証明された特発性肺線維 症患者由来の肺線維芽細胞は, 正常細胞に比較して in vitroでは $\mathrm{PDGF}$ や $\mathrm{TGF}-\beta$ 刺激に対する増殖反 応が低下，これらの刺激によるフィブロネクチン産 生は逆に充進していることが近年報告されたが40)， さらなる症例集積や異なる組織型での検討が必要で ある。

\section{ループス腎炎}

ループス腎炎の病態には免疫複合体沈着の他, 免
疫グロブリン受容体を介するシグナル伝達の関与が 知られている. 治療にはステロイドの他にシクロホ スファミドの bolus 療法やシクロスポリン, タクロ リムス，アザチオプリンが用いられ，近年ではミコ フェノール酸モフェチルの有用性が注目されている.

メサンギウム増殖を伴う様々な糸球体腎炎（IgA 腎症 12 例, Henoch-Schönlein 紫斑病性腎炎 4 例, び慢性増殖性ループス腎炎 4 例, 微少変化型ネフ ローゼ症候群 2 例）に扎いて, 健常腎 3 例に比べて PDGF-B や PDGF-R $\beta$ の発現が充進していること が mRNA 抢よび蛋白レベルで確認され, 特にび 慢性増殖性ループス腎炎は全例で PDGF-B や $\mathrm{PDGF}-\mathrm{R} \beta$ ともに強く発現発現していた ${ }^{41)}$. 従っ て,ループス腎炎においても PDGF 経路は治療標 的となりうると考えられた。

抗 Thy-1 抗体誘発性系球体腎炎モデルでは, Thy-1 抗体投与 8 時間前より 4 日間連日で PDGF に対する中和抗体を投与すると, メサンギウム細胞 の増殖やコラーゲン, ラミニンなどの ECM 産生が 抑制されることが報告された42)。また，PDGFのB 鎖に特異的に結合し阻害活性を発揮するオリゴ核酸 (アプタマー) は PDGF-BB 刺激によるメサンギウ 么細胞増殖を特異的に抑制し, 抗 Thy-1.1 抗体誘 発系球体腎炎モデルに打いても in vivoに打ける安 定性を高めるために PEG 結合した PDGF-B アプ タマーを投与するとメサンギウム増殖や内因性 PDGF-B 鎖発現, ECM 産生, そして軽度ながら単 球/マクロファージ浸潤を抑制した43).さらにメサ ンギウム細胞の PDGF $50 \mathrm{ng} / \mathrm{ml}$ 刺激による増殖を イマチニブが 0.013-2.0 $\mu \mathrm{M}$ で濃度依存性かつ特異 的に抑制することが示され（線維芽細胞増殖因子-2 刺激による増殖は抑制せず), 抗 Thy-1 抗体誘発性 系球体腎炎モデルでも $50 \mathrm{mg} / \mathrm{kg}$ のイマチニブ投与 は単球/マクロファージの遊走を阻害することなく メサンギウム増殖や ECM 増生を抑制した ${ }^{44)}$.

ループス腎炎モデルマウスでは，まず MRL/lpr マウスに打いて $50 \mathrm{mg} / \mathrm{kg}$ のイマチニブ投与により 系球体細胞増殖や半月体形成の抑制とともに生存延 長が見られた mRNA 発現低下のみならず抗 ds-DNA 抗体価の低 下も見られ，イマチニブの $\mathrm{T}$ 細胞に対する効果 ${ }^{46)}$ も示唆された。それから間もなく, (NZB/W $)$ F1 マウスにおいても $50 \mathrm{mg} / \mathrm{kg}$ にイマチニブ投与によ り, 蛋白尿発現の遅延, 腎機能障害の軽減, 糸球体 細胞増殖や免疫複合体沈着, 単球/マクロファージ 
浸潤などの抑制が認められることが報告された ${ }^{47)}$.

\section{SSc の皮膚硬化と肺高血圧症}

SSc の病態において血管障害に基づく虚血と過剩 な線維化反応が主体であり，例えばトロンビン刺激 によりPDGF 産生が充進するなど両者は密接に関 連している ${ }^{48)}$ ．昨年 PDGF-Rに対する自己抗体が SSc 患者血清に特異的に認められ，これがバセドウ 氏病における抗甲状腺刺激ホルモン受容体抗体のご とくPDGF-R に結合し，Ha-Ras, ERK1/2 を介し て線維芽細胞の活性酸素産生を六進させ, myofibroblast への変化やコラーゲン産生元進により線 維化病態に関与するという興味深い報告がなされ た ${ }^{49)}$. そして 2007 年初頭にイマチニブが PDGF や $\mathrm{TGF}-\beta$ 刺激による皮膚線維芽細胞のコラーゲン,

フィブロネクチン産生を阻害（非刺激時の産生も部 分的に抑制）し，ブレオマイシン皮下注により誘発 した皮膚の線維化もイマチニブ $50-150 \mathrm{mg} / \mathrm{kg}$ の腹 腔内投与で阻止することが報告された ${ }^{50)}$. In vivo に抢ける安全性の久ならず，in vitroの系で用いら れた 0.01-1.0 mg/1の用量で毒性がないことが， matrix metalloproteinases（MMPs）産生などに影 響しないことや，細胞の壊死やアポトーシスを生じ ないことで確認され，臨床的有用性を期待させるも のであった

肺高血圧症は膠原病では強皮症や混合性結合組織 病に合併しやすい極めて予後不良の病態である。近 年, PGI2 製剂であるエポプロステノールの持続静 注, シルデナフィルやエンドセリン受容体拮抗薬ボ センタンの経口投与が行われるようになった．肺高 血圧症の患者あるいは動物モデル（モノクロタリン 誘発抢よび低酸素誘発）の肺組織において PDGF$\mathrm{R} \beta$ の発現増強とリン酸化六進が認められ， 2 種の 動物モデルともイマチニブにより臨床的改善ととも に組織学的にも中膜肥厚や PDGF-B 鎖高発現の改 善が見られ，生存率も用量依存性に向上した ${ }^{51)}$ 。 そ して同グループから，シルデナフィルやボセンタン でコントロール不良であった肺高血圧症患者にイマ チニブ $200 \mathrm{mg} /$ day を投与したところ心機能が著明 に改善した症例が報告された ${ }^{52)}$.

おわりに

PDGF は従来型治療に抵抗性の様々な膠原病の 病態において重要な役割を果たしており,イマチニ ブによる PDGF さらには TGF- $\beta$ のシグナル伝達阻
表 1 イマチニブが有望な膠原病の病態と前臨床知見のまとめ

RA：滑膜線維芽細胞の transformation や増殖の阻害 $[26,27,29)]$ ，関節破壊の遅延 $[28,29)]$

間質性肺炎: 線維芽細胞の myofibroblastへの变化, 増 殖, ECM 産生え進などの阻害 [36-39) $]$

ループス腎炎：メサンギウム細胞増殖や ECM 産生, 半月 対形成などの抑制を介した蛋白尿の改善 と腎不全の阻止 $[45,47)]$

皮膚 硬 化: 線維芽細胞の myofibroblastへの変化, 増 殖, ECM 産生立進などの阻害 [50)

肺高血圧症 : 肺動脈に抢ける中膜肥厚の阻止による右室 圧や心拍出量, 酸素分圧の改善 [51)]

害療法は，線維芽細胞（または平滑筋細胞，メサン ギウム細胞）の増殖, 形質変化, ECM 産生などを 多面的に抑制することで病態を改善しうると考えら れる（表 1). また，肥満細胞やマクロファージ，

リンパ球など様々な細胞への作用がオーケストラ的 に作用すると考えられる. 病態の多様性に見合うだ けの治療の多様性を確立することが, 膠原病の治療 を大きく前進させると期待されるため, 欧米におけ る強皮症や肺高血圧症に対する臨床試験の経過を期 待して見守るとともに, 本邦独自の医師主導型臨床 試験を行って適応拡大を試みることが是非とも必要 である・

\section{文献}

1) Heldin C-H, Westermark B. : Mechanism of action and in vivo role of platelet-derived growth factor. Physiol Rev 79: 1283-1316, 1999.

2) Östman A, Heldin C-H. : Involvement of platelet-derived growth factor in disease: development of specific antagonists. Adv Cancer Res 80 : 1-38, 2001.

3) Pietras K, Sjöblom T, Rubin K, et al. : PDGF receptors as cancer drug targets. Cancer Cell 3 : 439-443, 2003.

4) Cheon H, Sun YK, Yu SJ, et al. : Platelet-derived growth factor-AA increases IL-1 $\beta$ and IL8 expression and activates $\mathrm{NF}-\kappa \mathrm{B}$ in rheumatoid fibroblast-like synoviocytes. Scand J Immunol 60 : 455-462, 2004.

5) Carroll M, Ohno-Jones S, Tamura S, et al. : CGP57148, a tyrosine kinase inhibitor, inhibits 
the growth of cells expressing BCR-ABL, TELABL, and TEL-PDGFR fusion proteins. Blood 90 : 4947-4952, 1997.

6) Druker BJ, Tamura S, Buchdunger E, et al. : Effects of a selective inhibitor of the Abl tyrosine kinase on the growth of Bcr-Abl positive cells. Nat Med 2 : 561-566, 1996.

7) Dewar AL, Cambareri AC, Zannettino ACW, et al. : Macrophage colony-stimulating factor c-fms is a novel target of imatinib. Blood 105 : 3127-3132, 2005.

8) Druker BJ, Talpaz M, Resta DJ, et al. : Efficacy and safety of a specific inhibitor of the BCRABL tyrosine kinase in chronic myeloid leukemia. N Engl J Med 344 : 1031-1037, 2001.

9) Druker BJ, Sawyers CL, Kantarjian H, et al. : Activity of a specific inhibitor of the BCR-ABL tyrosine kinase in the blast crisis of chronic myeloid leukemia and acute lymphoblastic leukemia with the Philadelphia chromosome. N Engl J Med; 344 : 1038-1042, 2001.

10) Demetri GD, von Mehren $M$, Blanke CD, et al. : Efficacy and safety of imatinib mesylate in advanced gastrointestinal stromal tumors. $N$ Engl J Med 347 : 472-480, 2002.

11) Apperley JF, Gardembas M, Melo JV, et al. : Response to imatinib mesylate in patients with chronic myeloproliferative diseases with rearrangements of the platelet-derived growth factor receptor beta. N Engl J Med 347 : 481-487, 2002.

12) George D.: Platelet-derived growth factor receptors: A therapeutic target in solid tumors. Semin Oncol 28 (suppl 17) : 27-33, 2001.

13) Choy EH, Panayi GS. : Cytokine pathways and joint inflammation in rheumatoid arthritis. $N$ Eng J Med 344 : 907-916, 2001.

14) Firestein GS, Zvaifler NJ. : How important are $\mathrm{T}$ cells in chronic rheumatoid synovitis? II. $\mathrm{T}$ cell-independent mechanisms from beginning to end. Arthritis Rheum 46 : 298-308, 2002.

15) Müller-Ladner U, Gay RE, Gay S. : Activation of synoviocytes. Curr Opin Rheumatol 12 : 186-194, 2000.

16) Yamanishi Y, Firestein GS. : Pathogenesis of rheumatoid arthritis: The role of synoviocytes. Rheum Dis Clin North Am 27 : 355-371, 2001.

17) Lafyatis R, Remmers EF, Roberts AB, et al. : Anchorage-independent growth of synoviocytes from arthritic and normal joints. Stmulation by exogenous platelet-derived growth factor and inhibition by transforming growth factor-beta and retinoids. J Clin Invest 83 : 1267-1276, 1989.

18) Müller-Ladner U, Kriegsmann J, Gay RE, et al. : Oncogenes in rheumatoid arthritis. Rheum Dis Clin North Am 21 : 675-690, 1995.

19) Imamura F, Aono $H$, Hasunuma $T$, et al. : Monoclonal expansion of synoviocytes in rheumatoid arthritis. Arthritis Rheum 41:19791986, 1998.

20) Müller-Ladner U, Kriegsmann J, Franklin BN, et al. : Synovial fibroblasts of patients with rheumatoid arthritis attach to and invade normal human cartilage when engrafted into SCID mice. Am J Pathol 149 : 1607-1615, 1996.

21) Kameda H, Risinger JI, Han B-B, et al. : Expression of Gab1 lacking the preckstrin homology domain is associated with neoplastic progression. Mol Cell Biol 21 : 6895-6905, 2001.

22) Rubin K, Terracio L, Ronnstrand L, et al. : Expression of platelet-derived growth factor receptors is induced on connective tissue cells during chronic synovial inflammation. Scand $J$ Immunol 27 : 285-294, 1988.

23) Remmers EF, Sano H, Wilder RL. : Plateletderived growth factors and heparin-binding (fibroblast) growth factors in the synovial tissue pathology of rheumatoid arthritis. Semin Arthritis Rheum 21 : 191-199, 1991.

24) Sano H, Engleka K, Mathern P, et al. : Coexpression of phosphotyrosine-containing proteins, platelet-derived growth factor-B, and fibroblast growth factor-1 in situ in synovial tissues of patients with rheumatoid arthritis and Lewis rats with adjuvant or streptococcal cell wall arthritis. J Clin Invest 91 : 553-565, 1993.

25) Watanabe N, Ando K, Yoshida S, et al. : Gene expression profile analysis of rheumatoid synovial fibroblast cultures revealing the overexpression of genes responsible for tumor-like growth of rheumatoid synovium. Biochem Biophys Res Commun 294 : 1121-1129, 2002.

26) Kameda H, Ishigami H, Suzuki M, et al. : Imatinib mesylate inhibits proliferation of rheumatoid synovial fibroblast-like cells and phosphorylation of Gab adapter proteins activated by platelet-derived growth factor. Clin Exp Immunol 144 : 335-341, 2006.

27) Sandler C, Joutsiniemi S, Lindstedt KA, et al. : Imatinib mesylate inhibits platelet derived 
growth factor stimulated proliferation of rheumatoid synovial fibroblasts. Biochem Biophys Res Commun 347 : 31-35, 2006.

28) Ando W, Hashimoto J, Nampei A, et al. : Imatinib mesylate inhibits osteoclastogenesis and joint destruction in rats with collagen-induced arthritis (CIA). J Bone Miner Metab 24 : 274282, 2006.

29) Paniagua RT, Sharpe O, Ho PP, et al. : Selective tyrosine kinase inhibition by imatinib mesylate for the treatment of autoimmune arthritis. $J$ Clin Invest 116 : 2633-2642, 2006.

30) Miyachi K, Ihara A, Hankins RW, et al. : Efficacy of imatinib mesylate (STI571) treatment for a patient with rheumatoid arthritis developing chronic myelogenous leukemia. Clin Rheumatol 22 : 329, 2003.

31) Eklund KK, Joensuu H. : Treatment of rheumatoid arthritis with imatinib mesylate: clinical improvement in three refractory cases. Ann Med 35 : 362-367, 2003.

32) Kameda $H$, Takeuchi $T$. : Recent advances in the treatment of interstitial lung disease in patients with polymyositis/dermatomyositis. Endocr Metab Immune Disord Drug Targets 6 : 409-415, 2006.

33) American Thoracic Society; European Respiratory Society. American Thoracic Society/European Respiratory Society Interstitial multidisciplinary consensus classification of the idiopathic interstitial pneumonias. Am J Respir Crit Care Med 165 : 277-304, 2002.

34) Kameda $H$, Nagasawa $H$, Ogawa $H$, et al. : Combination therapy with corticosteroids, cyclosporine $\mathrm{A}$, and intravenous pulse cyclophosphamide for acute/subacute interstitial pneumonia in patients with dermatomyositis. $J$ Rheumatol 32 : 1719-1726, 2005.

35) Sontheimer RD, Miyagawa S. : Potentially fatal interstitial lung disease can occur in clinically amyopathic dermatomyositis. $\mathrm{J} \mathrm{Am} \mathrm{Acad}$ Dermatol 48 : 797-798, 2003.

36) Daniels CE, Wikes MC, Edens M, et al. : Imatinib mesylate inhibits the profibrogenic activity of TGF- $\beta$ and prevents bleomycin-mediated lung fibrosis. J Clin Invest $114: 1308-1316$, 2004.

37) Abdollahi A, Li M, Ping G, et al. : Inhibition of platelet-derived growth factor signaling attenuate pulmonary fibrosis. J Exp Med 201 : 925-935, 2005.
38) Aono $\mathrm{Y}$, Nishioka $\mathrm{Y}$, Inayama $\mathrm{M}$, et al. : Imatinib as a novel antifibrotic agent in bleomycininduced pulmonary fibrosis in mice. $\mathrm{Am} J$ Respir Crit Care Med 171 : 1279-1285, 2005.

39) Chaudhary NI, Schnapp A, Park JE. : Pharmacologic differentiation of inflammation and fibrosis in the rat bleomycin model. $\mathrm{Am} \mathrm{J}$ Respir Crit Care Med 173 : 769-776, 2006.

40) Hetzel M, Bachem M, Anders D, et al. : Different effects of growth factors on proliferation and matrix production of normal and fibrotic human lung fibroblasts. Lung 183 : 225-237, 2005.

41) Matsuda M, Shikata K, Makino H, et al. : Gene expression of PDGF and PDGF receptor in various forms of glomerulonephritis. $\mathrm{Am} \mathrm{J}$ Nephrol 17 : 25-31, 1997.

42) Johnson RJ, Raines EW, Floege J, et al. : Inhibition of mesangial cell proliferation and matrix expression in glomerulonephritis in the rat by antibody to platelet-derived growth factor. $J$ Exp Med 175 : 1413-1416, 1992.

43) Floege J, Ostendorf T, Janssen U, et al. : Novel approach to specific growth factor inhibition in vivo. Antagonism of platelet-derived growth factor in glomerulonephritis by aptamers. $\mathrm{Am} \mathrm{J}$ Pathol 154 : 169-179, 1999.

44) Gilbert RE, Kelly DJ, McKay T, et al. : PDGF signal transduction inhibition ameliorates experimental mesangial proliferative glomerulonephritis. Kidney Int 59 : 1324-1332, 2001.

45) Sadanaga A, Nakashima $H$, Matsutani $K$, Miyake K, Shimizu S, Igawa T, Sugiyama N, Niiro H, Hirakata H, Harada M. : Amelioration of autoimmune nephritis by imatinib in MRL/lpr mice. Arthritis Rheum 52:39873996, 2005.

46) Seggewiss R, Loré K, Greiner E, Magnusson MK, Price DA, Douek DC, Dunbar CE, Wiestner A. : Imatinib inhibits $\mathrm{T}$-cell receptormediated $\mathrm{T}$-cell proliferation and activation in a dose-dependent manner. Blood 105 : 24732479, 2005.

47) Zoja C, Corna D, Rottoli D, Zanchi C, Abbate M, Remuzzi G. : Imatinib ameliorates renal disease and survival in murine lupus autoimmune disease. Kidney Int 70 : 97-103, 2006.

48) Ohba T, Takase Y, Ohhara M, et al. : Thrombin in the synovial fluid of patients with rheumatoid arthritis mediates proliferation of synovial fibroblast-like cells by induction of 
platelet-derived growth factor. J Rheumatol 23 : 1505-1511, 1996.

49) Baroni SS, Santillo M, Bevilacqua F, et al. : Stimulatory autoantibodies to the PDGF receptor in systemic sclerosis. N Engl J Med 354 : 2667-2676, 2006.

50) Distler JHW, Jungel A, Huber LC, et al. : Imatinib mesylate reduces production of extracellular matrix and prevents development of experimental dermal fibrosis. Arthritis Rheum
56 : 311-322, 2007.

51) Schermuly RT, Dony E, Ghofrani HA, et al. : Reversal of experimental pulmonary hypertension by PDGF inhibition. J Clin Invest 115 : 2811-2821, 2005.

52) Ghofrani HA, Seeger W, Grimminger F. : Imatinib for the treatment of pulmonary arterial hypertension. N Engl J Med 353 : 1412-1413, 2005. 